\title{
Abhidharma in early Mahāyāna ${ }^{1)}$
}

Johannes Bronkhorst

There is a growing tendency among scholars to discard questions about the (single) origin of Mahāyāna as inappropriate. Schopen (1975: 181 [52]) was perhaps the first to suggest a multiple origin, offering "the assumption that since each [Mahâyãna] text placed itself at the center of its own cult, early Mahâyâna (from a sociological point of view), rather than being an identifiable single group, was in the beginning a loose federation of a number of distinct though related cults, all of the same pattern, but each associated with its specific text." He was soon followed by Harrison (1978: 35), who observed that Mahâyāna "was from the outset undeniably multi-faceted." Some thirty years after his first assumption, Schopen stated again (2004: 492): "it has become increasingly clear that Mahāyāna Buddhism was never one thing, but rather, it seems, a loosely bound bundle of many, and $\cdots$ could contain $\cdots$ contradictions,

1) I have been able to profit from Douglas Osto's as yet unfinished article "Reimagining early Mahayāna: a review of the contemporary state of the field", which he kindly sent me; see also Osto, 2008: 106 ff.; Drewes, 2010. 
or at least antipodal elements." Silk (2002: 371) reminds us that "various earlỵ Nahâyāna sütras express somewhat, and sometimes radically, different points of riew, and often seem to have been written in response to diverse stimuli. For example, the tenor of such (apparently) early sütras as the Kaisjapaparivanta and the Rristrapalapariprocta on the one hand seems to have little in common with the logic and rhetoric behind the likewise

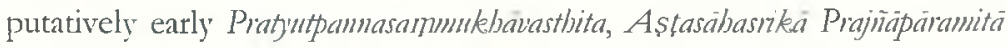
or Saddharma-pundarika on the other." Shimoda (2009: 7) suggests that "the Mahâyañna initially existed in the form of diverse phenomena to which the same name eventually began to be applied." Boucher (2008: xii) sums up recent work, saying: "Much of the recent scholarship on the early Mahâyañna points to a tradition that arose not as a single, well-defined, unitary movement, but from multiple trajectories emanating from and alongside Mainstream Buddhism." Sasaki (2009: 27) considers it "reasonable to assume that a multiplicity of originally discrete groups created a new style of Buddhism from their respective positions and produced their own scriptures and that with the passage of time these merged and intertwined to form as a whole the large current known as the Mahāyāna." He continues: "The Mahāyāna was a new Buddhist movement that should be regarded as a sort of social phenomenon that arose simultaneously in different places from several sources." Ruegg (2004: 33) emphasizes the geographic dimension: "The geographical spread of early Mahâyañna would appear to have been characterized by polycentric diffusion."2) A decade before him, Harrison (1995: 56) called Mahāyāna

2) Ruegg explains (p. 33-34): "From the start, an important part in the spread of Mahayana was no doubt played both by the Nothwest of the Indian subcontinent and by the Andhra country in south-central India, but presumably neither was the sole place of its origin. Bihar, Bengal and Nepal too were important centres 
"a pan-Buddhist movement - or, better, a loose set of movements."

This paper does not intend to find fault with these new insights into early Mahāyaña. However, it wishes to draw attention to a factor that is habitually overlooked in this discussion, namely, the dependence of most early Mahâyanana texts on the scholastic developments that had taken place during the final centuries preceding the Common Era, in northwestem India. ${ }^{3)}$ This, as we will see, may have chronological and geographical consequences. ${ }^{4)}$

Consider the following statement by Paul Williams (1989: 16): "It is sometimes thought that one of the characteristics of early Mahãyaña was a teaching of the emptiness of dharmas (dhamasizmata) - a teaching that these constituents, too, lack inherent existence, are not ultimate realities, in the same way as our everyday world is not an ultimate reality for the Abhidharma. ‥ As a characteristic of early Mahâyāna this is false." Williams then draws attention to some non-Mahāyẫna texts - the Lokaimuartana Suitra and the Satyasiddhi Sästra of Harivarman - that teach

of Mahayana. Sri Lanka also was involved in the history of the Mahayana ..."

3) An important exception is Harrison, 1978: 39-40: "[The philosophy of the Prajn̄aparamitā] attacked the qualified realism of the prevalent Sarvastivadins and held that all dhamas $\cdots$ are essentially empty (suma) and devoid of objective reality or 'owmbeing' (suabhāua)." Walser's recent book (2005) appears to overlook the direct or indirect dependence of many Mahayana works on northwestern scholasticism.

4) Peter Skilling (2010: 6) rightly reminds us "that the monastics who practised Mahayana took Sravaka vows, and shared the same monasteries with their fellow ordinands. Above all, we should not forget that those who practised Mahayana accepted the Sravaka Pitakas. They followed one or the other vinana, they studied and recited sutras, and they studied the abhidharma." The point to be made in this article is that, in order to study Sarvastivada Abhidharma, Sarvāstivada Abhidharma must exist, and one must have access to it. 
the emptiness of dharmas. In other words, Williams does not deny that the teaching of emptiness of dharmas is a characteristic of many early Mahâyaña works; he merely points out that the same teaching is also found in certain non-Mahâyāna works. David Seyfort Ruegg makes a similar observation (2004: 39): "The doctrine of the non-substantiality of phenomena (dharmanairännja / dharmanihsvabbavatā, i.e. svabhaiva-sinnyatä 'Emptiness of self-existence') has very often been regarded as criterial, indeed diagnostic, for identifying a teaching or work as Mahāyānist. For this there may of course be a justification. But it has nevertheless to be recalled that by the authorities of the Madhyamaka school of Mahāyānist philosophy, it is regularly argued that not only the Mahāyannist but even the Śẫvakayānist Arhat must of necessity have an understanding (if only a somewhat limited one) of dharmanairatmya." Once again, Ruegg does not deny that the emptiness of dharmas is a teaching that is almost omnipresent in early Mahâyâna texts. Like Williams, he merely points out that it is not limited to these texts.

Neither Williams nor Ruegg mention what I consider most important: that the very question of the emptiness or otherwise of dharmas is based on the ontological schemes elaborated in Greater Gandhāra, perhaps by the Sarvāstivãdins (but this is not certain). Numerous Buddhist texts, whether Mahâyāna or not, testify to the influence this ontology has come to exert on Buddhist thought all over India. However, this ontology had originally been limited to a geographical region, and may have taken a while before leaving this region.5) The fact that Mahâyana texts taught

5) This initial geographical limitation is not unique to Sarvastivada Abhidharma, and may have characterized many innovations in Indian philosophy. For a study of the initial geographical limitation (to Mithila) and subsequent spread of Navya-Nyaya techniques, see Bronkhorst, Diaconescu \& Kulkami, forthcoming. 
the emptiness of dharmas may not therefore signify that this is a typically or exclusively Mahāyāna position, but it does emphasize the dependence of much of Mahāyāna literature on developments that had begun in a small comer of northwestern India.6) The question is, did the Mahâyana texts concerned undergo this influence in Greater Gandhāra itself, or did they do so elsewhere, when the originally Gandharan ontology had spread to other parts of the subcontinent? The answer to this question cannot but lie in chronology: when did this Abhidharmic ontology leave Greater Gandhāra, and when were the earliest Mahăyāna texts composed that betray its influence? If these Mahẫyañna texts were composed before Abhidharmic ontology left Greater Gandhära, then these texts must have been composed in Greater Gandhāra.7)

With this in mind, let us look at a recent article by Allon and Salomon(2010). These two authors argue that the earliest evidence of Mahâyāna that has reached us comes from Gandhära "three $\cdots$ manuscripts have $\cdots$ been discovered which testify to the existence of Mahayana literature in Gãndhārī $\cdots$ reaching back, apparently, into the formative period of the Mahayana itself" (p. 9). They conclude "that the Mahayana was already a significant, if perhaps still a minority presence in the earlier period of the Buddhist manuscripts in Gandhāra" (p. 12). Allon and Salomon raise the question whether "Gandhāra played a formative role in the emergence of Mahayana," and whether texts like the ones that

6) So already Dessein, 2009: 53: "it appears that it was in the north that early Mahayanistic ideas were fitted into the framework of Sarvastivada abhidharmic developments." Cp. Skilling, 2010: 17 n. 49: "In the Bodhicaryauatara (chap. 9 , v. 41), a rhetorical opponent of the Mahayana questions the usefulness of the teaching of emptiness: it is the realization of the Four Truths of the Noble that leads to liberation - what use is emptiness?"

7) Perhaps Kaśmira, too, should be taken into consideration; see below. 
have survived "were originally composed in this region" (p. 17). They" caution that these types of texts may have been available at other major Buddhist centers throughout the subcontinent during this period: "It is merely the subcontinental climate, which is so deleterious to the preservation of organic materials, that has denied us the evidence" ( $p$. 17).

Allon and Salomon's caution is justified and appreciated. However, as observed above, the region of Greater Gandhära did not only distinguish itself from other Buddhist regions through its climate, or through its exceptional aptitude to preserve manuscripts that could not survive elsewhere. The Buddhism of Greater Gandhära distinguishes itself equally through the intellectual revolution that had taken place there during the centuries immediately preceding the Common Era. It is here that the modification and elaboration of Abhidharma took place that became the basis of virtually all forms of subcontinental Buddhism. Clearly Greater Gandhära was not just one other Buddhist center. It may be justified to consider it the most important Buddhist center of the Indian subcontinent around the beginning of the Common Era.8) The fact that it has a climate that is favorable to the preservation of organic materials may be looked upon as a fortunate extra.9)

8) See also Salomon, 1999: 178-180 ("Gandhāra as a Center of Buddhist Intellectual Activity").

9) Note that in subsequent centuries "palm leaf writing material came from the South", but "no southem scripts or (Buddhist) texts were found in the Turfan collections studied by Sander [1968: 25]." Houben \& Rath therefore wonder (2012: 3 n. 6): "Can we conclude that southern Buddhist schools, if they had any independent existence, were not authoritative in the North?" Not yet aware of the Mahayana texts found in Gandhara, Houben \& Rath (2012: 38 n. 62) suggest the southern parts of the Indian subcontinent as a possible or even likely area of origin of Mahayana ideas. 
Consider now the following. Allon and Salomon draw attention to various early fragments of early Mahāyana texts that have recently become available. The following passage in their article is of particular interest (p. 10):

The so-called "split" collection of Gāndhārī manuscripts, which has not yet been published but which is being studied by Harry Falk, contains a manuscript with texts corresponding to the first (on the recto side) and fifth (verso) chapters of the Aștasăhasnikã Prajñăpăramitâ. This scroll has been radiocarbon dated to a range of 23-43 CE (probability 14.3 percent) or $47-127$ (probability 81.1 percent), and a date in the later first or early second century $\mathrm{CE}$ is consistent with its paleographic and linguistic characteristics. Therefore in thị Gāndhārī Prajnăpāramitā manuscript we have the earliest firm dating for a Mahayana sutra manuscript in any language, as well as the earliest specific attestation of Mahayana literature in early Gandhära.

Falk's article has meanwhile come out (2011) and studies, among other things, the manuscript referred to in this passage. We learn from it ( $\mathrm{p}$. 20) that "[a] comparison with the Chinese translation of Lokakșema, dated 179/180, and the classical version as translated by Kumārajīva clearly shows a development from a simple to a more developed text. The Gāndhärī text looks archaic and is less verbose than what Lokaksema translated. It can be shown that his version was already slightly inflated by the insertion of stock phrases, appositions and synonyms. The Sanskrit version, finally, expanded still further."

At the same time, certain copying blunders indicate that the Gandhanta manuscript was itself copied from another one which was written in 
Kharoșțhī as well (Falk \& Karashima, 2012: 22).

The special point to be emphasized is that the "Perfection of Wisdom," which is the subject matter of the Astasähasriké Prajnäparamitä10) in its surviving Sanskrit version, only makes sense against the background of the overhaul of Buddhist scholasticism that had taken place in Greater Gandhära during the last centuries preceding the Common Era. It was in Greater Gandhẵa, during this period, that Buddhist scholasticism developed an ontology centered around its lists of dharmas. Lists of dharmas had been drawn up before the scholastic revolution in Greater Gandhāra, and went on being drawn up elsewhere with the goal of preserving the teaching of the Buddha. But the Buddhists of Greater

Gandhāra were the first to use these lists of dharmas to construe an ontology, unheard of until then. They looked upon the dharmas as the only really existing things, rejecting the existence of entities that were made up of them. Indeed, these scholiasts may have been the first to call themselves simyavadins. ${ }^{11)}$ No effort was spared to systematize the ontological scheme developed in this manner, and the influence exerted by it on more recent forms of Buddhism in the subcontinent and beyond was to be immense. But initially this was a geographically limited phenomenon. ${ }^{12)}$ It may even be possible to approximately date the beginning of this intellectual revolution. $I$ have argued in a number of publications that various literary and philosophical features of the grammarian Patañali's (Vyäkarana-) Mababbasyla must be explained in the light of his acquaintance with the fundamentals of the newly developed

10) The Gāndhari text calls itself, in a colophon, just Prajñaparamita.

11) In their Vijñanakaya see Bronkhorst, 2009: 120, with a reference to La Vallee Poussin, 1925: 358-359. See further Salomon, 1999: 178.

12) See Bronkhorst, 1999; 2009: 81-114. 
Abhidharma. ${ }^{13)}$ This would imply that the intellectual revolution in northwestern Buddhism had begun before the middle of the second century BCE. If it is furthermore correct to think, as I have argued elsewhere, that this intellectual revolution was inspired by the interaction between Buddhists and Indo-Greeks, it may be justified to situate the beginning of the new Abhidharma at a time following the renewed conquest of Gandhāra by the Indo-Greeks; this was in or around 185 BCE. 14) The foundations for the new Abhidharma may therefore have been laid toward the middle of the second century BCE.

It is not known for how long this form of Abhidharma remained confined to Greater Gandhāra. There is, as a matter of fact, reason to think that Kasimira was implicated in this development virtually from its beginning. ${ }^{15)}$ It is here that the three extant Vibhäsâa compendia were composed. The most recent of these three, the Mabâuibhäșá, refers to the "former king, Kanișka, of Gandhāra."16) Kanișka's realm appears to have begun in $127 \mathrm{CE} .{ }^{17}$ ) The Mabauribbassăa is presumably younger than this, but not much. The other two Vibbäsăs are slightly older, and may therefore belong to the first century CE. However, indirect evidence pushes the date further back. Already the Vibbassa reports the bad treatment Buddhists underwent under Pusyamitra, presumably in Kaśmīra. ${ }^{18)}$ Puşyamitra was a ruler with whom the grammarian Patañjali was associated.

13) Bronkhorst, 1987: 43-71; 1994; 2002; 2004: esp. §§ 8-9.

14) See Salomon, 2005 , which is based on an interpretation of the yavana era. For a different interpretation of this era, with references to the relevant literature, see Falk, 2012: 135-136. See further Salomon, 2012; Golzio, 2012: 142.

15) Indeed, the map given by Salomon (1999: 2) suggests that he includes Kasimira in "Greater Gandhära"; Behrendt (2004: 16, 22) does so explicitly.

16) Willemen, Dessein \& Cox, 1998: 232; Dessein, 2009: 44.

17) Falk, 2001; see further Golzio, 2008.

18) Lamotte, 1958: $424 \mathrm{ff}$. 
There are reasons to think that Patañali himself lived in Kaśmīra in the middle of the second century BCE. Patañali betrays familiarity with a number of fundamental concepts of Sarvāstivāda scholasticism. ${ }^{19}$ )

This form of Abhidharma subsequently spread beyond Greater Gandhāra and Kaśmīra. ${ }^{20)}$ Perhaps Nāgārjuna is the first author from a different region and familiar with the new Abhidharma whose writings have been preserved. ${ }^{21)}$ Nāgārjuna's date appears to be the end of the second or the beginning of the third century $\mathrm{CE}$.22) Inscriptional evidence confirms that there were Sarvāstivādins in northem India outside Gandhāra from the first century $\mathrm{CE}$ onward. ${ }^{23)}$ In other words, the scholastic form of Abhidharma developed in Greater Gandhära and Kaśmira spread beyond this region at least from the first century $\mathrm{CE}$ on.24)

19) See note 12, above. On Patañjali’s link to Kaśmira, see Bronkhorst, forthcoming, with references to further literature. Note that the word Sarvastivanda is here used in a general and imprecise manner; it is not at all certain that the early Abhidharma developments in northwestern India belonged to that school in particular.

20) The spread of Sarvastivada Abhidharma may have to be distinguished from the spread of the Sarvastivadins themselves. With regard to the latter, Schopen (2004a: 41 n. 34) draws attention to inscriptions referred to in Bareau, 1955: 36 (inscription of the 2nd cent. CE from "près de Peshawer, dans l'Ouest du Cachemire, à Mathurà et à Çrâvastî"), 131-132, and the sources there cited; Lamotte, 1958: 578 (earliest Sarvastivāda inscription in Mathura, 1st cent. CE; cp. Konow, 1969: 30 ff.); Willemen et al., 1998: 103-104 (monastery at Kalawān with earliest mention in an inscription of the Sarvâstivādins, $77 \mathrm{CE}$ according to Hirakawa, 1993: 233); Salomon, 1999: 200, 205 (according to Salomon, it is "likely that rayagaha- [in this inscribed potsherd] referred to a place of that name, presumably named after the original Rajagrha in Magadha, renowned in Buddhist tradition", p. 213).

21) The influence of the new Abhidharma on Jainism, to, may go back to an early date and a region different from Greater Gandhära; see Bronkhorst, 2011: $130 \mathrm{ff}$.

22) Walser, 2002; 2005: 86.

23) See note 18 , above. 
The Astasabasrikas Prajnäparamita, as are other texts of the same genre,25) is largely built on the scholastic achievements of Greater Gandhāra; it draws conclusions from these. One of its recurring themes is its emphasis that everything that is not a dharma does not exist. This is the inevitable corollary of the conviction that only dharmas really exist, but one that is rarely emphasized in the Abhidharma texts. The Astasaibasrika Prajiaparamita goes further and claims that the dharmas themselves do not exist either, that they are empty (simya). Once again, all this only makes sense against the historical background of the Abhidharma elaborated in Greater Gandhāra. Another recurring theme concerns the beginning and end of dharmas. This is clearly the elaboration of a question with which the scholiasts of Greater Gandhära were confronted: did they have to postulate the existence of a dharma called "beginning" (jati, utpatt) in order to account for the fact that dharmas, being momentary, have a beginning in time? The scholiasts explored this possibility, and ended up with improbable dharmas such as "the beginning of beginning" (jatijata). The position taken in numerous Mahâyañna texts is that dharmas have no beginning (and no end). 'This makes perfect sense among thinkers who are steeped in Gandharan scholasticism, but nowhere else.

Let us look at one passage from the Aștasähassiké Prajniaparamiata. Without

24) For the relative chronology of the earlier Abhidharma works, see Dessein, 1996. We should not forget, of course, that the grammarian Patanjali was already acquainted with the fundamental notions of the new Abhidharma soon after 150 BCE. Different signs point in the direction that Patañjali lived in Kasmira; see Bronkhorst, forthcoming.

25) Roger Wright kindly draws my attention to Conze's (1960: 11) mention of the Arapacana chapter of the Satasahasrika Prajñaparamita as evidence for its northwestem onigin. There is indeed evidence to think that the Arapacana syllabary had its origin in Gandhara (Salomon, 1990; Falk, 1993: 236-239). 
the prior conviction that only dharmas exist, it is pointless to claim that something does not exist because it is not a dharma. Yet this is the point frequently made in the Asţasabasrikä Prajnäpäramitä. Consider the following passage, in the abbreviated translation of Edward Conze (1958: 1-2):

Thereupon the Venerable Subhūit, by the Buddha's might, said to the Lord: The Lord has said, "make it clear now, Subhüti, to the bodhisattvas, the great beings, starting from perfect wisdom, how the bodhisattvas, the great beings go forth into perfect wisdom!" When one speaks of a 'bodhisattva', what dharma does that word 'bodhisattva' denote? I do not, O Lord, see that dharma 'bodhisattva', nor a dharma called 'perfection of wisdom.' Since I neither find, nor apprehend, nor see a dharma 'bodhisattva', nor a 'perfection of wisdom', what bodhisattva shall I instruct and admonish in what perfection of wisdom? And yet, O Lord, if, when this is pointed out, a bodhisattva's heart does not become cowed, nor stolid, does not despair nor despond, if he does not turn away or become dejected, does not tremble, is not frightened or terrified, it is just this bodhisattva, this great being who should be instructed in perfect wisdom.

Ontological issues like this, relating to the question whether this or that item is a dharma, or indeed whether dharmas themselves exist, fill the first chapter of the Astasaibasizia Prajnäparamita one of the two chapters of which parts have been preserved on the manuscript from Gandhāra. Is this already true of the early manuscript from Gandhära?

The edition of the manuscript from Gandhẩa in a recent article by Falk \& Karashima (2012: 32-35) shows that it already contains this passage 
in essence. There is one major difference: the Gandhâra manuscript emphasizes that 'bodhisattva' is not a dharma, but does not say the same about the 'perfection of wisdom', as does the surviving Sanskrit text. The Chinese translation of Lokakșema, too, is without this information about the 'perfection of wisdom'. This allowed Schmithausen (1977: 44 f.), some thirty-five years, ago to argue that our text originally only spoke of the non-existence of the bodhisattva, not of the non-existence of the "perfection of wisdom" (Prajñaparamitä). ${ }^{26)}$ This is now confirmed by the Gandhāra manuscript.

This example should suffice to show that the manuscript from Gandhăra dealt with at least some of the philosophical issues that had been raised and developed in Greater Gandhāra.

Let us get to the main point. The Gändhārì manuscript, or rather the text it contains, may conceivably have been composed when this kind of Abhidharma thought was still the exclusive property of Greater Gandhāra. If so, this text was itself composed in Greater Gandhāra, or indeed in Gandhăra proper, ${ }^{27}$ ) and it becomes tempting to conclude

26) Schmithausen (1977: $44 \mathrm{f}$.) concludes from this that the passage was enlarged, so as to include, beside the pudgalanairatmy that is behind the non-existence of a bodhisattva, also the Mahayanist dhamanairatrma, which is behind the non-existence of Prajñāpāramitā. This conclusion is doubtful. It is based on the assumption that Prajñaparamita is a dharma. This assumption conflicts both with the wording of the passage under consideration - tom apy aham bhagauan dharmamn na somanupaśyami yad uta prajñaparamita năma "I do not, O Lord, see a dharma called 'perfection of wisdom'" - and, to the best of my knowledge, with the traditional lists of dharmas. It is true that prajña "wisdom" figures in those lists, but praȳināpanaramitā does not. Just as the scholiasts distinguished between dharmas and their beginning, or birth (jati), they would presumably distinguish between "wisdom" and the "perfection of wisdom"; the former exists (because it is a dharma), the latter does not (because it is not a dharma). 
that the kind of Mahâyañna to which it gives expression began in that part of the subcontinent.

This tentative conclusion is in need of specification. What is being discussed is the kind of Mahāyana that leans heavily on the scholastic developments initiated in Greater Gandhära. This may signify that the kind of Mahâyana that draws inspiration from the scholastic innovations of Greater Gandhära might possibly have originated there. The same is not necessarily true of Mahāyaña in all of its forms. The bodhisattva ideal, after which Mahāyāna is also known as Bodhisattva-yâna, ${ }^{28)}$ may well exist without the scholastic ideas elaborated in Greater Gandhära, and may indeed have existed without them.29) This is the conclusion

27) Cf. Falk \& Karashima, 2012: 20: "It is hardly far-fetched to assume that this text had its origins in Gandhāra proper; that is in the Peshawar valley with its tributaries, including the adjoining region of Taxila." With respect to Bactria, Fussman (2011: 36), summing up a discussion, states: "On dira donc que la présence au moins occasionnelle de moines mahayanistes a Kara-Tepa et Fajaz-Tepa n'est pas exclur, qu'elle est même probable, mais qu'il n'existe aucun indice le demontrant." The nikaya-affiliation of these two monasteries was mahāsãnghika (id., p. 35).

28) Note however Samuels, 1997; Appleton, 2010: 91-108.

29) Cf. Ruegg, 2004: 51: "no single philosophical doctrine and no single religious practice - not even the bodhisattva-ideal or the suabhāua-sunyata(nihsuabhāıata) or dhamanairätrma doctrine - can of and by itself be claimed to be the main religious or philosophical source of the Mahayana as a whole." Ruegg presumably includes the bodhisattva-ideal in this enumeration because this ideal also existed outside Mahayana; see the preceding note. $\mathrm{Cp}$. Schopen, 2004: 493-494: "There is $\cdots$ a kind of general consensus that if there is a single defining characteristic of the Mahayana it is that for Mahayâna the ultimate religious goal is no longer nirvana, but rather the attainment of full awakening or buddhahood by all. This goal in one form or another and, however nuanced, attenuated, or temporally postponed, characterizes virtually every form of Mahayana Buddhism that we know." Vetter (1994; 2001) argues "against the generally held notion that Mahayana and Prajnaparamita are identical, and for the thesis that the two came together at a certain moment in time, and 
that one is tempted to draw from various passages in both Mahâyâna and Mainstream (Sarvāstivãda) texts collected bỵ Fujita (2009). There were apparently Buddhists who pursued the goal of becoming Buddhas, i.e. they were bodhisattras, and yet they did not follow many of the distinctive teachings that we find in most Mahāyāana texts. ${ }^{30}$ )

This is even true of a text that is usually considered a Mahāyañna text, presumably one of the oldest that has survived, the Ugrapariprecclassitra. ${ }^{31)}$ Natrier (2003: 179 ff.) draws attenrion to what she calls "the absence of the rhetoric of absence itself." She explains, "the Ugra lacks anything that could be construed as a "philosophy of emptiness." She concludes (p. 182): "It is tempting, therefore - and it may well be correct to view the Ugra as representing a preliminary stage in the emergence of the bodhisattva vehicle, a phase centered on the project of 'constructing' ideas about the practices of the bodhisattva that preceded a later 'deconstructionist' - or better, dereifying - move."

It is clear from Nattier's remark that she is tempted to order the Ugrapariprccbasititra chronologically. This tendency presents her with some difficulties, in that the Ugrapariprccläsutita is not the only Mahayana Sütra that ignores the "philosophy of emptiness": it shares this feature with the Aksobbyauyizita and the Sukbavativyziba, both of which seem

yet did not always and everywhere remain united." (2001: 59)

30) See further Ruegg, 2004: 11 with note 15. Fujita's article relies heavily on Sarvastivada materials, but suggests that there may have been bodhisattvas also in other Nikayas. The Sarvastivadins, needless to add, were the very Buddhists who elaborated, or at any rate preserved, the scholastic ideas of Greater Gandhara here under discussion. Williams's (1989: 26 ff.) discussion of the Ajitasena Sutra may be of interest here.

31) Nattier (2003: 10) cautiously specifies that the Ugrapariprcchasutra "should not $\cdots$ be called a 'Mahayana sūtra' - not, that is, without considerable qualification." 


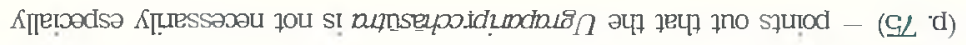
9002 '

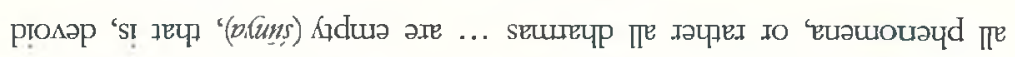

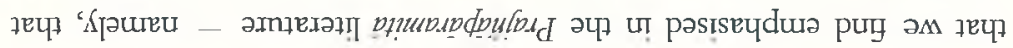

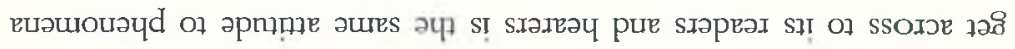

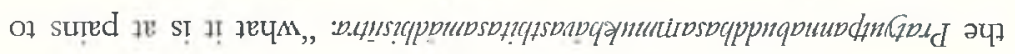

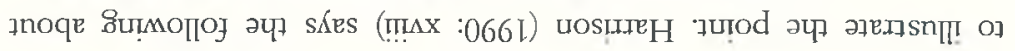

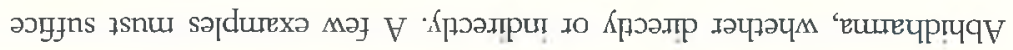

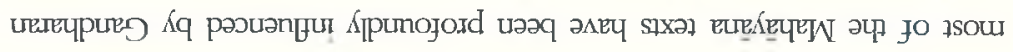

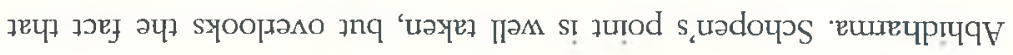

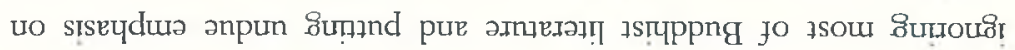

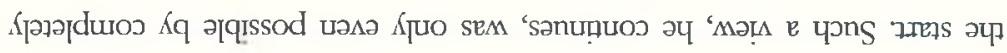

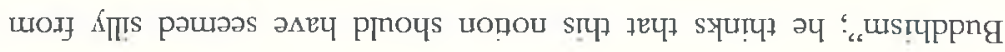

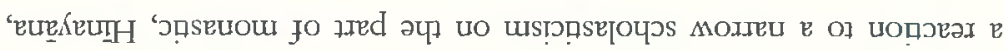

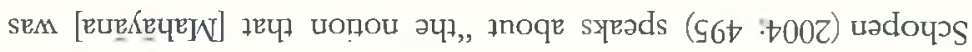

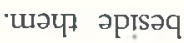

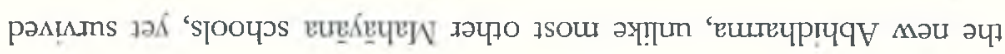

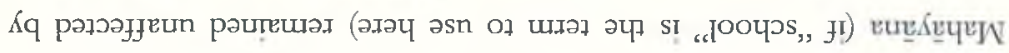

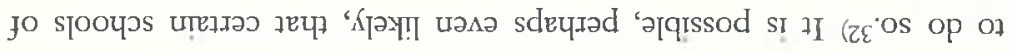

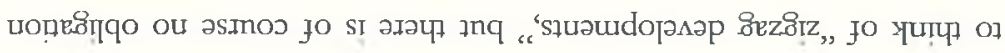

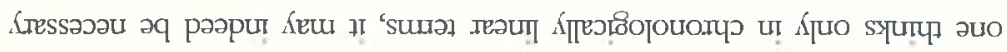

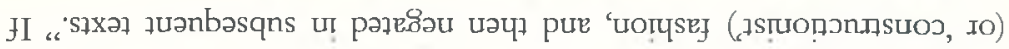

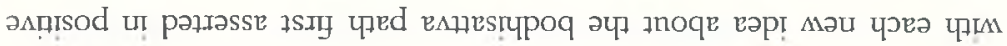

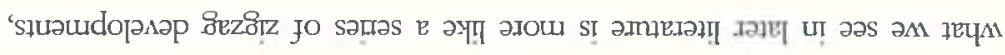

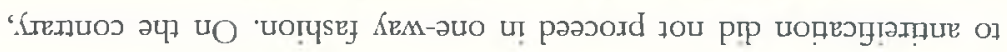

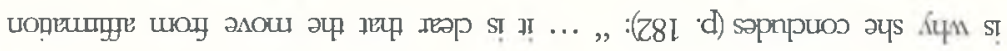

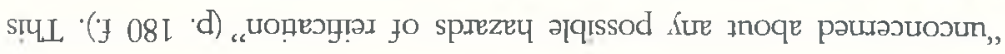


of essence, independent existence or 'own-being' (svabbava). Since this is so, there is nothing which can provide a basis for 'apprehension' or 'objectification' (upalambha), by which term is intended that process of the mind which seizes on the objects of experience as entities or existing things (bhaxa), and regards them as possessing an independent and objective reality."33) About the Suramgamasamadbisutia, Lamotte (1965/1998: 40-41) observed: "The essential aim of the [Surramgamasamaidbisutra] is to inculcate into its listeners or readers the Pudgala- and Dharmanairātmya. Not only do beings not exist, but things are empty of self-nature, unarisen, undestroyed, originally calm and naturally abiding in Nirvaña, free of marks and in consequence inexpressible and unthinkable, the same and devoid of duality." Once again we are here confronted with the kind of thought that could only arise on the basis of Gandharan Abhidharma. About the Ratnakuita texts, Pagel (1995: 100) observes: "Like practically all other Mahāyāna sūtras, the Ratnakūtạ's bodhisattva texts operate within the gnoseologic parameter of Mahâyana ontology. This is most ostensibly borne out by the frequency with which they draw connections with its axioms of emptiness (sumyatâ), sameness (samatä) and non-objectifiability (ampalambha) that most accept as the philosophic substratum for their exposition." The following passage from the Käsyapaparivarta shows the preoccupation of this text, too, with the ontological status of dharmas: ${ }^{34)}$

This also, Kầsyapa, is the middle way, the regarding of dharmas in

33) See however Harrison, 1978: 55: "In its interpretation of a 'Mahayana-ised' form of buddhanusmati in terms of the doctrine of Sunnyata [the Pratyutpanna-sütra] reveals tensions within the Mahayāna."

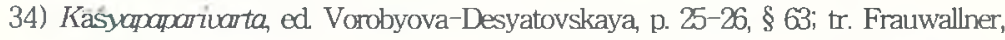
1969/2010: 178-179 (replacing factors with dharmas); cp. Weller, 1970: 122-123 [1201-1202]. 
accordance with truth: that one does not make the dharmas empty through emptiness but, rather, the dharmas themselves are empty; that one does not make the dharmas signless through the signless but, ather, the dhamas themselves are signless; $\cdots$ that one does not make the dharmas unarisen through non-arising, but, rather the dharmas themselves are unarisen; that one does not make the dharmas unborn through not being born, but, rather, the dhamas themselves are unborn; and that one does not make the dharmas essenceless through essencelessness (astabhanata), but, rather, the dharmas themselves are essenceless.

Even Sütras that lay less emphasis on "philosophy" often betray that they, too, accept ideas that are based on Gandharan scholasticism. The Saddharmopundarkasistra, for example, lays relatively little emphasis on these ontological concerns, ${ }^{35)}$ but it is not, in its present form, without them. Consider the following passage, in which the Buddha criticizes the follower of the Srāvakayāna: ${ }^{36}$

Therefore the follower of the Srâvakayana [who has cut his various

35) Cf. Nattier, 2003: 181: "Even the Lotus Sutra - widely read through the lens of 'emptiness' philosophy by both traditional East Asian sumuata, and in general seems more concerned with urging its listeners to have faith in their own future Buddhahood than in encouraging them to 'deconstruct' their concepts."

36) Saddharmap(V) p. 93 1. 9-15; Saddharmap(W) p. 127 1. 2-11: tena śräıakayāujy d. evaan janati, evam ca vacam bhāsate: na santy auxare dhamāa abhisamboddharyāh nirvānaprāpto 'smiti/ atha khalu tathāgatas tasmai dharman desayati/ yena sarvadharma na praptah, kutas tasya nirvanam iti? tam bhagcuan bodhau sannādàpanati/ sa utpomnabodhicitto na samsarasthito na niruānaprapto bhauati/ so vabudhya traidhätukam daśasu dikșu sūnyam nimitopanam māyopamam suapnanaricipratiśrutkopamam lokam pasyati/ sa sarvadharman anutpannan aniruddhan abaddhān amuktan atamondhakāān naprakaśan paśyati/. Cp. Kotsuki, 2010: V.44 b.1-3 (p. 66-67); Mizufune, 2011: V.56 b.5 - 57a.1 (p. 81-82). 
ties] thinks like this and speaks like this: "There are no other dharmas to be realized. I have reached Nirraña."

Then the Tathaggata teaches him the Doctrine. He who has not attained all dhammas, how can Nirraña belong to him? The Lord establishes him in enlightenment: $\mathrm{He}$ in whom the thought of enlightenment has arisen is not in Samsāa nor has he reached Nirvāna. Having understood, he sees the unirerse in all ten directions as being empty (sirin'a), similar to something fabricated, similar to magic, similar to a dream, a mirage, and echo. He sees all dharmas as not having arisen, as not having come to an end, not bound and not loose, not dark and not bright.

Here the preoccupation with the ontological status of dharmas is evident, but it is not impossible that this portion is a late addition to the text. ${ }^{37}$ ) The Rasstrapalapariprchasistra, too, concentrates on other issues than ontology, but reveals its ontological position in several passages, such as the following: ${ }^{38}$ )

Like a lion, [the Blesssed One] announces that all dharmas are without substratum and are empty $\cdots$ Just as a lion, roaring in a mountain cave, frightens prey here in the world, so too does the Lord of Men, resounding that [all dharmas] are empty and without substratum, frighten those adhering to heretical schools. $\cdots$ Focused on emptiness and signlessness, he considers all conditioned things to be like illusions.

37) Karashima, 2001: 172: "The portion in the Lotus Sutra where we can clearly see the influence of the sunyata thought system, is in the second half of the Osadh-parivarta (V). Hence this verse portion, which is not found in Kumarajiva's translation, is thought to have been interpolated at a much later time." See further Vetter, 2001: $83 \mathrm{ff}$.

38) RP p. 2 1. 9; p. 3 1. 15-16 (tr. Boucher, 2008: 114-115). On the presence of old Äryaverses in this text, see Klaus, 2008. 
According to Osto (2008: 19), "the Gandavyizha, while not specifically" elaborating a Madhyamaka or Yogäcâra position, contains passages that support aspects of both schools." What this means is that "all phenomena (dharmas) lack inherent existence or independent essence (svabbäva) and therefore are characterized by their emptiness (śünjatâ)" (p. 18).

It follows from our reflections that Gandharan influence may conceivably have modified an already existing preoccupation with the path to Buddha-hood. This earlier preoccupation with Buddha-hood might in that case not have originated in Greater Gandhāra. But even if this were to be the case, it could still be maintained that the elements in Mahāyāna that depend on the scholastic innovations of Greater Gandhära - the ontological tendency, the interrogations about the existence of this or that dharma or about dharmas in general, the concern with emptiness, the wish to abolish conceptual constructs (vikalpa) - were introduced in that part of the subcontinent. It follows from the above that early Mahāyāna may have drawn inspiration from the intellectual revolution that had taken place in Greater Gandhära. It is even possible that it underwent this influence, at least initially, in that very region.

Clearly this proposal does not necessarily tell us much about the origin or origins of Mahāyāna. It does tell us something about the geographical region in which it may have originated, or through which it passed in an early phase. It can therefore be combined with theories that do try to explain the origin of Mahāyaña. Consider, for example, Drewes's (2010a: 70; also 2011) suggestion "that early Indian Mahāyāna was, at root, a textual movement that developed in Buddhist preaching circles and centered on the production and use of Mahāyāna sūtras." Drewes specifies: "At some point, drawing on a range of ideas and theoretical perspectives 
that had been developing for some time, and also developing many new ideas of their own, certain preachers began to compose a new type of text - sūtras containing profound teachings intended for bodhisattvas - which came to be commonly depicted as belonging to a new revelation that the Buddha arranged to take place five hundred years after his death." If we accept this theory, which I do not insist we must, we would like to know which were those "ideas and theoretical perspectives that had been developing for some time." The intellectual revolution that had taken place in Greater Gandhära will then immediately come to mind as providing at least a part, an important part, of those ideas and theoretical perspectives.

\section{References:}

Allon, Mark \& Salomon, Richard (2010): "New evidence for Mahayana in early Gandhāra." EB 41(1), 1-22.

Appleton, Naomi (2010): Jataka Stories in Theravada Buddbism. Narrating the Bodlhisatta Path. Farnham: Ashgate.

Bareau, André (1955): Les sectes bonddhiques du petit vébicule. Paris: École Française d'Extrème-Orient. (Publications de l'École Française d'Extrème-Orient, 38.)

Behrendt, Kurt A. (2004): The Buddhist Architecture of Gandbära. Leiden etc.: Brill. (Handbook of Oriental Studies, 2/17.)

Boucher, Daniel (2008): Bodhisattvas of the Forest and the Formation of the Mahayana: A Study and Translation of the Rasstrapalapariprechä-sütra. Studies in the Buddhist Traditions. Honolulu: University of Hawai'i Press.

Bronkhorst, Johannes (1987): Three Problems Pertaining to the Mahäbhäsya. Poona: Bhandarkar Oriental Research Institute. (Post-Graduate and Research Department Series, No. 30. "Pandit Shripad Shastri Deodhar Memorial Lectures" [Third Series].) 
Bronkhorst, Johannes (1994): "A note on Patañjali and the Buddhists." Ammals of the Bbandarkar Oriental Research Institute 75, 247-254.

Bronkhorst, Johannes (1999): IV'by' is there pbilosopby in India?, Amsterdam: Royal Netherlands Academy of Arts and Sciences. 1999. (Sixth Gonda lecture, held on 13 November 1998 on the premises of the Royal Netherlands Academy of Arts and Sciences.)

Bronkhorst, Johannes (2002): "Patañjali and the Buddhists." Buddhist and Indian Studies in Honour of Professor Sodo Mori. Hamamatsu: Kokusai Bukkyoto Kyokai (International Buddhist Association). Pp. 485-491.

Bronkhorst, Johannes (2004): From Panini to Patanjali: the search for linearty. Pune: Bhandarkar Oriental Research Institute. (Post-graduate and Research Department Series, 46.)

Bronkhorst, Johannes (2009): Buddhist Teaching in India. Boston: Wisdom Publications.

Bronkhorst, Johannes (2011). Buddhism in the Shadow of Brabmanism. I eiden Boston: Brill. (Handbook of Oriental Studies 2/24.)

Bronkhorst, Johannes (forthcoming): "Vedic schools in northwestern India." Proceedings of the Fifth International Vedic Workshop, Bucharest, 20-23 Seprember 2011.

Bronkhorst, Johannes; Diaconescu, Bogdan \& Kulkarni, Malhar (forthcoming): "The arrival of Navya-Nyāya techniques in Varanasi: a preliminary exploration." An Indian Ending: Rediscorering the Grandesur of India for a Sustainable Lifestyle: A Festschrift in Honor of Ptof John Vattanky; SJ. Ed. Kuruvilla Pandikattu. Delhi: Serial Publishers. Pp. 85-117 (?)

Conze, Edward (tr.)(1958): Asţasahasrikà Prajüäpanamita. Calcutta: Asiatic Society. Second impression, 1970. (Bibliotheca India 284/1592.)

Conze, Edward (1960): The Prajī̄päranuitä Liferature. 's-Gravenhage: Mouton. (Indo-Iranian Monographs, 6.)

Dantinne, Jean (1991): Les qualités de l'ascète (dbutaguna): Etude sémantique ef doctrinale. Thanh-long.

Dessein, Bart (1996): "Dharmas associated with awareness and the dating of Sarvāstivāda works." AS 50(3), 623-651.

Dessein, Bart (2009): "The Mahāsāmghikas and the origin of Mahayana 
Buddhism: Evidence provided in the Abhidharmamahãvibhẫșâsăāstra." EB $40(1 / 2), 25-61$.

Drewes, David (2010): "Earlỵ Indian Mahậ̂ảna Buddhism I: Recent scholarship." Religion Compass 4(2), 55-65.

Drewes, David (2010a): “Early Indian Mahâyāna Buddhism II: New perspectives." Religion Compass 4(2), 66-74.

Drewes, Darid (2011): "Dharmabhāṇakas in early Mahâyaàna." III 54, 331-372. Enomoto, Fumio (2000): “Nưlasarvẩstivādin' and 'Sarvâstivâdin."” I iridharatnakarandaka. Festgabe fir. Adelbeid Mette. Ed. Christine Chojnacki, Jens-Uwe Hartmann \& Volker M. Tschannerl. Swisttal-Odendorf: Indica et Tibetica. (Indica et Tibetica, 37.) Pp. 239-250.

Falk, Harry (1993): Schrift im alten Indien. Ein Forschungsbericht mit Anmerkungen. Tübingen: Gunter Narr. (ScriptOralia, 56.)

Falk, Harny (2001): "The yuga of the Sphujiddhraja and the era of the Kușānas." Silk Road Art and Arcbaeology 7, 121-136.

Falk, Harry (2011): “The 'split' collection of Kharoșthī texts." ARIRIAB 14 (for the academic year 2010), 13-23.

Falk, Harry (2012): "Ancient Indian eras: an overview." Bulletin of the Asia Institute N.S. 21 [2007], 131-145.

Falk, Harry \& Karashima, Seishi (2012): “A first-century Prajn̄ẩaăramitā manuscript from Gandhãra - parivarta 1. (Texts from the Split Collection 1)." ARIRIAB 15 (for the academic year 2011), 19-61.

Frauwallner, Erich (1969/2010): The Pbilosopby of Buddbism Die Pbilosophie des Buddbismms). Translated by Gelong Lodro Sangpo with the assistance of Jigme Sheldrön, under the supervision of Ernst Steinkellner. Delhi: Motilal Banarsidass.

Fujita, Yoshimichi (2009): “The bodhisattva thought of the Sarvâstivaadins and Mahẩâna Buddhism." = Saitô, 2009: 99-120.

Fussman, Gérard (2011): Monuments bouddbiques de Termez, / Termez Buddhist Monuments, I: Catalogue des inscriptions sm poteries. Avec une contribution de Nicholas Sims-Williams et la collaboration d'Eric Ollivier. I, 1: Introduction, catalogues, commentaires. I, 2: Planches, index et concordances, résumés. Paris: Collège de France; Diffusion De Boccard. 
(Publications de l'Institut de Civilisation Indienne, 79,1-2.)

Golzio, Karl-Heinz (2008): “Zur Datierung des Kuşâna-Königs Kanișka I.”

Bauddhasabityastabakasiali. Essan's and Studies on Buddhist Sanskrit Literature

Dedicated to Claus Vogel by Colleagues, Students, and Friends. Ed. Dragomir

Dimitrov, Michael Hahn \& Roland Steiner. Marburg: Indica et Tibetica Verlag. (Indica et Tibetica, 36.) Pp. 79-91.

Golzio, Karl-Heinz (2012): "Zu in Gandhầra und Baktrien verwendeten Ären."

Zeitscbrift der Deutscben Morgenländiscben Gesellschaft 162(1), 141-150.

Harrison, Paul (1978): "Buddhânusmr̨ti in the Pratyutpanna-buddhasammukhāvasthita-samâdhi-sūtra." Journal of Indian Pbilosopby 6, 35-57

Harrison, Paul (1990): The Samadbi of Direct Encounter with the Buddhas of the Present. An annotated English translation of the Tibetan version of the Pratyutpanna-Buddha-Sammukhāvasthita-Samâdhi-Sũ̃tra with several appendices relating to the history of the text. Tokyo: The International Institute for Buddhist Studies. (Studia Philologica Buddhica, Monograph Series, 5.)

Harrison, Paul (1995): "Searching for the origins of the Mahâyâna: what are we looking for?" $\mathrm{EB} \mathrm{28(1),} 48-69$.

Hirakawa, Akira (1993): A History of Indian Buddhism: From Sakyamuni to early Mahayana. Translated and edited by Paul Groner. Delhi: Motilal Banarsidass. (Buddhist Tradition Series, 19.)

Houben, Jan E. M. \& Rath, Saraju (2012): "Introduction. Manuscript culture and its impact in 'India': contours and parameters." Aspects of Manuscript Culture in Soutb India. Ed. Saraju Rath. Leiden - Boston: Brill. (Brill's Indological Library, 40.) Pp. 1-53.

Karashima, Seishi (2001): "Who composed the Lotus Sutra? Antagonism between wilderness and village monks." ARIRIAB 4, 145-182.

Karashima, Seishi (2011): A Critical Edition of Lokaksema's Translation of the Aștasabasrika Prajñäparamita. Tokyo: The Intemational Research Institute for Advanced Buddhology, Soka University. (Bibliotheca Philologica et Philosophica Buddhica, 12.)

Klaus, Konrad (2008): "Metrische und textkritische Untersuchungen zur Rāștrapālapariprcchā. Die alten Ātyā-Strophen." Bauddhasabityastabakāvalī. 
Essays and Studies on Buddhist Sanskrit Literature Dedicated to Claus Vogel by Colleagues, Students, and Friends. Ed. Dragomir Dimitror, Nichael Hahn, and Roland Steiner. Marburg: Indica et Tibetica Verlag. (Indica et Tibetica, 36.) Pp. 199-228.

Konow, Sten (ed.)(1969): Kharoshthi Inscriptions, with the exception of those of Asoke.

Varanasi: Indological Book House. (Corpus Inscriptionvm Indicarvm, vol. II, part I.)

Kotsuki, Haruaki (ed.)(2010): Saddharmapundarikasuitram. Sanskrit Lotus Sutra Mamuscript from Cambridge University Library' (Add. 1684), Romanized Text. Tokyo: Soka Gakkai.

Lamotte, Etienne (1958): Histoire dr bosddbisme indien. Des origines à leere Saka. Louvain: Inscitut Orientaliste. (Bibliothèque du Musçon, 43.)

Lamotte, Etienne (tr.)(1965/1998): Suramgamasamadbisutra. The Concentration of Heroic Progress. An early Mahāyāna Buddhist scripture translated and annotated [into French]. English translation by Sara Boin-Webb. Surrey: Curzon Press / London: The Buddhist Society.

La Vallée Poussin, Louis de (1925): "La controverse du temps et du Pudgala dans le Vijñāyakāya." Études Asiatiques 1 (Publications de l'École Française d'Extrème-Orient vol. XIX), 343-376.

Mizufune, Noriyoshi (ed.)(2011): Saddharmapundarikasitram. Sanskrit Lotus Sutra Masuscript from the British Librany (Or. 2204), Romanized Text. Tokyo: Soka Gakkai. (Lotus Sutra Manuscript Series 11.)

Nattier, Jan (2003): A Few Good Men: The Bodbisattua Path according to The Inquiny of Ugra (Ugrapariprccbä). Honolulu: University of Hawaii Press.

Osto, Douglas (2008): Ponver, Wealth and Women in Indian Mabayana Buddhism: The Gandaywiha-sutra. London \& New York: Routledge.

Pagel, Ulrich (1995): The Bodhisattvapitaka. Its doctrines, practices and their position in Mabjayana literature. Tring: The Institute of Buddhist Studies. (Buddhica Britannica, series continua V.)

Pagel, Ulrich (2006): "About Ugta and his friends: a recent contribution on early Mahâyañna Buddhism. A review article." Josmal of the Royal Asiatic Society, Series 3, 16(1), 73-82.

Ruegg, David Seyfort (2004): "Aspects of the study of the (earlier) Indian 
Mahāyāna." Joumual of the International Association of Buddhist Strdies 27(1), 3 -62 .

Saitō, Akira (ed.)(2009): Mabajyana Buddhisns: Its Origins and Reality. = Acta Asiatica: Bulletin of the Institute of Eastem Culture 96.

Salomon, Richard (1990): "New evidence for a Gāndhārī origin of the Arapacana syllabary." Joumal of the American Oriental Socieb 110(2), 255-273. Salomon, Richard (1999): Ancient Buddbist Scrolls from Gandhara. The British Libran' Khansthi Fragments. London: The British Library.

Salomon, Richard (2005): "The Indo-Greek era of 186/5 BC in a Buddhist reliquary inscription." Afghanistan: ancien camefour entre l'est et l'aust. Ed. Osmund Bopearachchi \& Marie-Françoise Boussac. Turnhout: Brepols. Pp. 359-401.

Salomon, Richard (2012): "The Yona Era and the end of the Maurya dynasty: Is there a connection?" Reimagining Asoka. Memory and History. Ed. Patrick Olivelle, Janice Leoshko \& Himanshu Prabha Ray. Oxford University Press. Pp. 217-228.

Samuels, Jeffrey (1997): "The bodhisattva ideal in Theravãda Buddhist theory and practice: a reevaluation of the bodhisattva-ŝanaka opposition." Philosopby East and West 47(3), 399-415.

Sander, Lore (1968): Palaographisches z"l den Sanskitthandschriften der Berliner Tufansammlung. Wiesbaden: Franz Steiner. (Verzeichnis der Orientalischen Handschriften in Deutschland, Supplementband 8.)

Sasaki, Shizuka (2009): "A basic approach for research on the origins of Mahāyāna Buddhism." Acta Asiatica 96, 25-46.

Schmithausen, Lambert (1977): "Textgeschichtliche Beobachtungen zum 1. Kapitel der Așțasāhasrikâ Prajñāpāramitā." Prajnäpăramita and Related Systems. Studies in honor of Edward Conze. Ed. Lewis Lancaster. Berkeley: University of Califomia. (Berkeley Buddhist Studies Series, 1.) Pp. 35-80. Schopen, Gregory (1975): "The phrase sa prthivipradeśas caityabhüto bhavet in the Vajracchedikā." IIJ 17, 147-181. Reprinted with stylistic changes in Schopen, 2005: 25-62.

Schopen, Gregory (2004): "Mahāyāna." Encyclopedia of Buddhism. Ed. Robert E. Buswell. New York etc.: Macmillan Reference USA. Vol. 2, pp. 492-499. 
Schopen, Gregory (2004a): Buddlist Monks and Business Matters. Still more papers on monastic Buddhism in India. Honolulu: Lniversity of Hawai'i Press.

Schopen, Gregory (2005): Figments and Fragments of Mabajana Buddbism in India: More Collected Papers. Honolulu: University of Hawai'i Press.

Shimoda, Masahiro (2009): "The State of research on Mahayyana Buddhism: The Mahăyāna as seen in developments in the study of Mahāyāna Sútras." = Saitō, 2009: 1 - 23.

Silk, Jonathan A. (2002): "What, if anỵthing, is Mahâyẫna Buddhism? Problems of definitions and classifications." Numen 49, 355 - 405.

Skilling, Peter (2002): Review of Fnomoto, 2000. IIJ 45(4), 373-377.

Skilling, Peter (2010): "Scriptural authenticity and the Srâvaka schools: an essay towards an Indian perspective." EB, New Series 41(2), 1-47.

Vetter, Tilmann (1994): "On the origin of Mahāyāna Buddhism and the subsequent introduction of Prajñăpāramirā.” AS 48(4), 1241-1281.

Vetter, Tilmann (2001): "Once again on the origin of Mahâyăna Buddhism." WZKS 45, 59-90.

Vorobyova-Desyatovskaya, M. I. (2002): The Kasyapaparivarta. Romanized text and facsimiles. In collaboration with Seishi Karashima \& Noriyuki Kudo. Tokyo: The International Research Institute for Advanced Buddhology, Soka University.

Walser, Joseph (2002): "Năgărjuna and the Ratnâvalĩ: new ways to date an old philosopher." JIABS 25(1-2), 209-262.

Walser, Joseph (2005): Nagariuna in Context: Mabayana Buddhism and Early Indian Culture. New York: Columbia University Press.

Weller, Friedrich (1970): "Käsyapaparivarta nach der Han-Fassung verdeutscht." Buddhist Y'early (1968/69[1970]), 57-221. = KISchr pp. 1136-1304.

Willemen, Charles; Dessein, Bart \& Cox, Collett (1998): Sarvastivida Buddhist Scholasticism. Leiden etc.: Brill. (Handbook of Oriental Studies 2/11.)

Williams, Paul (1989): Mabajana Buddhism. The doctrinal foundations. London \& New York: Routledge.

Wynne, Alexander (2008): "On the Sarvâstivâdins and Mūlasarvâstuvâdins." Indian Intermational Joumal of Buddbist Studies 9, 243-266. 
Abbreviations:

ARIRIAB

AS

ASP(Vaidya)

$\mathrm{BBu}$

BST

EB

IIJ

KISchr

RP

Saddharmap(V)

Saddharmap (W)

WZKS
Annual Report of the International Research Institute for Advanced Buddhology at Soka University

Asiatische Studien, Études Asiatiques, Bern

Aștasäbasrikä Prajiäparamitā, ed. P. L. Vaidya, Darbhanga 1960 (BST 4)

Bibliotheca Buddhica, St. Petersburg (Leningrad)

Buddhist Sanskrit Texts, Darbhanga

The Eastern Buddhist, Kyôto

Indo-Iranian Journal, Den Haag, Dordrecht

Kleine Schriften [Glasenapp-Stiftung], Wiesbaden, Stuttgart

Rästrapälapariprccha, ed. L. Finot, Petersburg 1901 (BBu 2) Saddharmapundarkassitra, ed. P. L. Vaidya, Darbhanga 1960 (BST 6)

Saddharmapundarikaswira, ed. U. Wogihara and C. Tsuchida, Tokyo, 1958

Wiener Zeitschrift für die Kunde Südasiens, Wien

요하네스 브롱코스트(Johannes Bronkhorst)는 라이덴 대학에서 박사학 위를 받았으며, 현재 스위스 로잔대학교(Lausanne Univ.)의 명예교수이다. 초 기불교 및 자이나 사상과 관련된 분야의 연구에 매진하고 있다. 주요 저서로 는 Theoretical Aspects of Paninis Grammar(1980), The Two Traditions of Meditation in Ancient India(1986), The Two Sources of Ancient Indian Asceticism(1993) 등이 있으며, 이외에 다수의 논문이 있다.

*이 글은 불교학연구원에서 주최한 <해외석학 초청강연회>(2012. 12. 4)에 서 발표된 것이다. 